\title{
Types and Ratio of Functionally and Stylistically Colored Synonyms from G. Matyukovskiy's Poetry in the Hill Mari Language
}

Tatyana N. Belyaeva

Natalya V. Bogdanova

Andrey V. Rychkov

Irina V. Trubyanova

Yelena L. Yandakova

Mari State University, Yoshkar-Ola, Russia

Email: opleva@mail.ru

Doi:10.5901/mjss.2015.v6n3s7p127

\begin{abstract}
The article is devoted to analysis of functional and stylistic coloring of synonyms and their quantitive proportions in the poetry of G. Matyukovskiy in the Hill Mari language. The study identified three main groups of synonyms belonging to different functional styles: colloquial and bookish style synonyms, and commonly used synonyms. Among the synonyms of the colloquial style we revealed components of synonymous series with daily colloquial, low colloquial, and rude colloquial functional stylistic coloring. Some of the synonyms of the bookish style are specified in belonging to a functional style and refer to scientific or belles-letter style. Synonyms of the belles-letter style have poetic, traditional poetic and folk poetic coloring. We give a brief description of functional styles and functional-stylistic colorings that are characteristic to the synonyms in the works by G. Matyukovskiy. The paper contents comparison of number of commonly used and functionally colored synonyms to identify proportions, reflected in the form of tables and charts. We described the language of the author on the basis of quantitative proportions. The data obtained can be used for compiling and adding the synonym dictionary of the Hill Mari language, which is expected to be published.
\end{abstract}

Keywords: Hill Mari language, synonym, functional style, functional stylistic coloring, ratio.

\section{Introduction}

Synonyms play an important role in transmission of expressiveness and conciseness of the language of a literary work. Synonyms can help to define social and cultural background of characters, to express the author's attitude to characters and events, to give a special tone to the narrative. The study of lexical and stylistic features of the Hill Mari language is necessary for preservation and development of the language of one of the small nations of Russia.

The analysis of synonyms' functional and stylistic coloring and the subsequent establishment of quantitive proportions has not previously been made in the Hill Mari language, so the subject of investigation is the novelty of the study. We made an attempt to allocate groups of synonyms which belong to various functional styles. The results showing quantitative characteristics are presented in the table 1 and figure 1.

Topicality is determined by the need to create a dictionary of synonyms of the Hill Mari language in which the designation of functionally and stylistically colored components of synonymous series is required. While determining the functional and stylistic coloring of synonyms, we relied on a dictionary of a Hill dialect of the Mari language by A.A. Savatkova (Savatkova, 1981), as well as contextual use of synonyms by G. Matyukovskiy in his works.

Methods used in the paper are the following: hypothetical-deductive, which consist in selection of factual material, its generalization with the use of inductive method, making hypothesis and deductive identification of new results; method of equipollent opposition, according to which semantic and stylistic differences of synonyms are identified on the basis of similarity of their denotative meaning; method of gradual opposition, which helps to identify synonyms with varying degree of expression of their semantic shades of meaning and stylistic coloring; component method, which allows to expand the meaning of synonyms into semantic components; contextological method, which takes into account the influence of context on the meaning of synonyms; statistical method, whereby quantitative ratios of different categories of synonyms 
are derived.

The examples of synonymous series are built according to the rules of compiling synonymous dictionaries: there is a dominant at the beginning, followed by synonyms closest in meaning having neutral stylistic coloring, stylistically coloured synonyms are given at the end of the series; we give common meaning of the series, translation of each component, stylistic usage marks.

We have chosen 281 work by G. Matyukovskiy, including rune translations of Karelian-Finnish epic "Kalevala", as a source for the study. The choice in favor of this author has been made due to brightness, expressiveness and originality of this outstanding Mari poet. People's poet G. Matyukovskiy made a great contribution to the development of the Mari literature. His career lasted from the late 30's to early 90-ies of the XX-th century. Writer's language is one of manifestations of a literary language, so the analysis of synonyms in the poetry of $\mathrm{G}$. Matyukovskiy will expand the knowledge about stylistic potential of the Hill Mari language.

Earlier connotation of synonyms in the works by G. Matyukovskiy was studied (Opleva, 2009). Synonyms were regarded as tropes (Opleva, 2009). Stylistic coloring of phraseological synonyms in the Hill Mari language on the basis of works by G. Matyukovskiy was also investigated (Trubyanova, 2013).

Functional and stylistic coloring of a lexical unit indicates its use in a particular functional style. More than $19 \%$ of the total number of synonyms in the works by G. Matyukovsky have functional and stylistic coloring (Table 1).

Figure 1. Ratio of synonyms with different functional-stylystic colouring

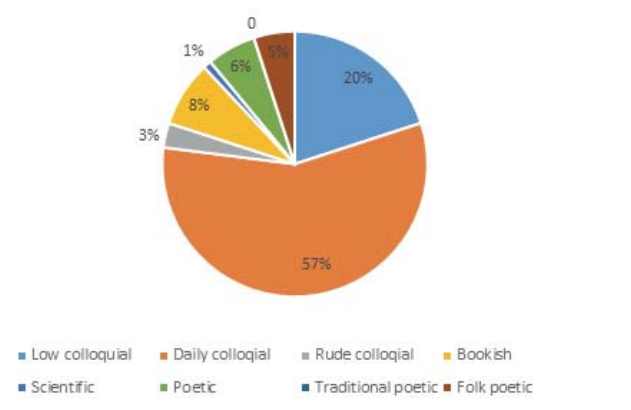

Table 1. Ratio of synonyms having different functional-stylistic coloring with the total number of all the synonyms revealed in the works of G. Matyukovskiy.

\begin{tabular}{|c|c|c|c|c|}
\hline \multicolumn{5}{|c|}{ Synonyms from the works by G. Matyukovskiy } \\
\hline & nctional style & Functional-stylistic colouring & Quantity & Percentage \\
\hline \multirow{3}{*}{\multicolumn{2}{|c|}{ Colloquial }} & Daily colloquial & 168 & $11,2 \%$ \\
\hline & & Low colloquial & 59 & $3,9 \%$ \\
\hline & & Rude colloquial & 8 & $0,5 \%$ \\
\hline \multicolumn{3}{|c|}{ Total number of colloquial synonyms } & 235 & $15,4 \%$ \\
\hline \multicolumn{2}{|c|}{ Bookish } & & 25 & $1,6 \%$ \\
\hline \multirow{4}{*}{ 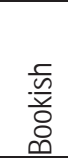 } & Scientific & & 4 & $0,3 \%$ \\
\hline & \multirow{3}{*}{ Belles-letter } & Poetic & 17 & $1,2 \%$ \\
\hline & & Traditional poetic & 1 & $0,07 \%$ \\
\hline & & Folk-poetic & 14 & $0,9 \%$ \\
\hline \multicolumn{3}{|c|}{ Total number of bookish synonyms } & 61 & $4 \%$ \\
\hline \multicolumn{3}{|c|}{ Total number of synonyms with functional-stylistic colouring } & 296 & $19,4 \%$ \\
\hline \multicolumn{3}{|c|}{ Total number of commonly used synonyms } & 1229 & $80,5 \%$ \\
\hline \multicolumn{3}{|c|}{ Total number of synonyms of all types } & 1525 & $100 \%$ \\
\hline
\end{tabular}

Functional styles are an extensive system, in which vocabulary is distributed into two main styles, colloquial and bookish, under the influence of linguistic and extralinguistic factors.

According to the tradition of components' description of the synonymous series in dictionaries of synonyms functional and stylistic coloring of synonyms is indicated with special mark. Synonyms of the daily colloquial style, which are used in everyday conversation, have a mark (daily col.), in low colloquial the speech mark is (low col.) and in familiar 
and rude-familiar the speech mark is (rude col.).

The most relevant feature of vocabulary's defining of the everyday speech is free expression within literary norms. (Kozhina, 2006).

Low colloquial synonyms differ with more reduced stylistic coloring from daily colloquial ones. They do not conform to literary norms. Low colloquial words are available with limited stylistic tasks as means of social and speech characteristics of characters for "reduced" characteristics of persons, objects, events in the expressive terms in the literal language (Kozhina, 2006).

For comparison of the daily colloquial and low colloquial vocabulary, we will analyse a number of examples from synonymous series with the dominant высаш v. 'race'. The general meaning of the series is "to move forward at high speed."

The component чукташ $v$. (literally: light) 'fly, hit the road, jerk, run very fast, escape' refers to the daily colloquial style; мырыкташ v. 'ride off, run away, escape' has a coloring of a low colloquial style: Теве, лудде анжальн, чуктыш анзык йожалm (Matyukovskiy, 1996). 'So with a fearless eye he rushed forward' Вара налешат корзиным, / Пачым веле кыйырта, / Ныр покшак, крахмаллан лин / Паша годым мырыкта (Matyukovskiy, 1996). 'Then, having taken the basket, he will run away during the work with just sparkling heels, having come for starch, from the middle of the field'.

Functional and stylistic coloring of rude colloquial synonyms are complemented by expressive negative emotional evaluations. Examples of rude colloquial synonyms are words characterizing fascists in the works by G. Matyukovskiy: немчура n. 'nemchura', фрашист-zad n. 'fascist-bastard', фрашист-nu n. 'fascist-dog', nu-фpaшuсm n. 'dog - fascist' these words are used in daily speech with coloring of contempt, for example: Булатвланат кыньыльы рота / Шалаташ, лыпшаш немчурам (Matyukovskiy, 1996). 'The troop of Bulat got up to break, crush nemchura'.

The following components of the synonymic series have bright daily and low colloquial coloring: Йyaw $v$. (daily col., disparaging), лочкаш v. (low col., disparaging), лопыргаш v. (low col., disparaging).

The common meaning is 'to take, swallow some drinking'. Йуаш v. 'drink'; лочкаш v. 'guzzle'; лопыргаш v. 'drink clumsily and carelessly', лочкаш, and лопыргаш have disparaging shade.

Льктеш пеллитр аракам. - / Только, шумбел, йуаш шалт (Matyukovskiy, 1986)! 'He takes out half a liter of vodka. - Drink, friend, just in one gulp'. Но техень мындыр житяжы / Кужы ылде когонжок, / Лочкым шолтым аракажы/ Тыдым комдык пиштыш йок (Matyukovskiy, 1996). 'But such a gay life has not lasted for a long time, brew, which he got drunk, knocked him tightly'. Кольм анзыцынжы Слон / Йалым тымден со: «Ида йу - / Вет арака худа пиш когон...», - / Шкежы лопырген ведра дон (Matyukovskiy, 1983). 'Before the death, Elephant touch others, "Don't drink - vodka is very harmful..." - and he drank clumsily and carelessly with buckets'.

Among these examples лочкаш is used in everyday speech, лопыргаш is met in low colloquial language.

Synonyms with daily colloquial coloring constitute the larger part of the total number of synonyms in poetry of $G$. Matyukovskiy $-11.2 \%$. Low colloquial synonyms are 3.9\%, rude colloquial ones are $0.5 \%$ (Table 1).

Among stylistically marked synonyms more than half of the components (57 \%) of the synonymous series have daily colloquial coloring in the works by G. Matyukovskiy. $20 \%$ of synonyms have low colloquial coloring. $3 \%$ of synonyms have rude colloquial coloring.

Scientific, official-business, publicistic and belles-letter styles are the varieties of the bookish style.

In the scientific style terms are used from the different fields of science, culture, art, economics, medicine, sports etc. In dictionaries terms related to the scientific style have a speech mark (spec.) - special, or more specifically (anat.) anatomical, (bot.) - botabical, (med.) - medical. In belles-letter speech, terms are found in limited quantities. Special vocabulary is often characterized as the layer of words which don't have synonyms. However, parallel scientific terms can be referred to category of absolute synonyms.

The words borrowed from Russian language can belong to terminological vocabulary. They can head a synonymic series, e.g.:

Кормы $n$. (spec.), качкыш $n$. (col.).

What is eaten by animals. Кормы 'feed for a cattle' belongs to cattle-breeding terminology; качкыш 'meal, food' in the meaning of 'feed' is used in everyday colloquial speech. Имни сила вел чыдемын, / Слабка эче тыдыжат. / Кормы пытен шынзын (Matyukovskiy, 1986). 'Horses became less, and they are weak. Food is over'. Туран анжен, пистолетым / Викта тыды рвезы вык: / - Ыштем качкышым капетым / Курныжлан сейчас (Matyukovskiy, 1986)! 'Glowering, he pointed the gun at the boy: "I'll make food from you for kites!'

Synonyms of the scientific style, which include scientific terms, constitute only $1 \%$ of the total amount of synonyms with functional-stylistic coloring in the considered sources (Fig. 1).

The assignment of synonyms of bookish style to the official-business and publicistic style are usually specified in the explanatory text. 
A. P. Yevgenyeva divides the words belonging to the official-business style into officialese and official-business layers of vocabulary (Yevgenyeva, 2003). The words, used in official correspondence, registration of current documentation, belong to officialese style. As it is noted in "Stylistic encyclopedic dictionary of the Russian language", the substyles of the official-business style are legislative, jurisdictional, administrative (Kozhina, 2006).

The official-business vocabulary is rarely used in poetic language, therefore the data from the works of $G$. Matyukovskiy are not sufficient for highlighting the components and number of sub-groups of synonyms of the official style. An example of a lexical unit of the official-business style is the word документ $n$. 'document' with a synonym from the daily colloquial speech пумага $n$. (lit:: paper) 'document': Йыле, йыле документвлам / Лыкташ, лыкташ цилаге (Matyukovskiy, 1996)! 'Faster, faster, carry out the documents, carry out everything!' Эртен кеш верема, / Ойхым шораш манын, / Токыжы кандевы / Пенсилан пумагам (Matyukovskiy, 1996). 'Time has passed, to dispel grief, the documents were brought to her for pension registration'.

The using of officialese документ and daily colloquial пумага gives the persons' speech expressive and stylistic characteristics appropriate to high and low styles.

Words of publicistic style are used in a wide range of social spheres: politics, economics, culture, sport, agriculture. The characteristic features of the publicistic style vocabulary are expressiveness and informative value, manifested in objectivity of presentation and some officiality.

The coloring of the publicistic style has the word kpax n. 'failure, crash', which is used in the field of economic relations. Its emphatic meaning creates the additional expressiveness. The word кpax can be compared with its synonym каnуm n. 'ruin, destruction, end' used in daily colloquial speech: Рынг! Рунг! Трах! Бах! / Тылат толеш, тышман, крах (Matyukovskiy, 1996)! 'Rumble! Noise! Bang! Bah! Your crash is approaching, enemy!' Да шкеат пытеда, чучын / Керем онгышкы, - каnуm (Matyukovskiy, 1986)! 'You will die, seemed in the loop of the rope, kaput!'

The distinctive features of the scientific, official-business and publicistic vocabulary are not always perceived with sufficient certainty, and therefore the stylistic characteristics of a significant number of words are evaluated as bookish. Peculiarities of the bookish vocabulary are borrowings. In the works by G. Matyukovskiy the colouring of bookish style is shown in the words mpacca $n$. 'road for vehicles', шоссегорны $n$. 'road paved with gravel', which were borrowed from Russian language. The dominant of the series is корны $n$. 'way, road'.

Кырык вылны шоссекорны / Кеа азым нырвла гач. / Мынь ти корныш пишок толнем, / Тышты шачмы сола ач (Matyukovskiy, 1986). 'There is a paved highway on the hill of sowing fields. I really want to go down this road, there is my native village'. Сек анзыц техень кого трассыш / Высалты да шаныш пишок: / - Тылзыш келеш шоаш да Марсыш, / Да палныш шыдырвла докок (Matyukovskiy, 1996). 'He went before all in such a long journey, and thought: - It is necessary to fly to the moon and Mars, and to the distant stars'.

The number of synonyms which can be marked as 'bookish' is $8 \%$ of the total number of functionally colored synonyms (Fig.1).

The traditional basis of belles-letter style is made of the poetic layer of lexis marked in dictionaries by the words "poetic", "folk-poetic", "traditional-poetic" (Kozhina, 2006). The poetic lexis is distinguished by special stylistic character of emotionality, lyricism, softness, sincerity, pathetic tone of narration. Due to special tonality the poetic lexis is considered as a part of elevated style making lexis. The mark (folk-poet.) specifies that the word has entered into a literary language from oral folk poetry and keeps folklore colour (Gorbachevich, 2008). A.P. Yevgenyeva says, that the reason for introducing the mark (trad.-poet.) is the originality of poetic speech which includes stylistic means, methods of bellesletter expressiveness, verse structure. Linguistic (as well as lexical) tradition in poetry is much firmer, than in prose. The poetry represents an area which comprises lexical elements, admissible and possible only in it (Yevgenyeva, 2003).

In the works by $\mathrm{G}$. Matyukovskiy we can identify a number of words that have the mentioned characteristics of poetic language. For example, in a synonymous series with a dominant кымылангаш $v$. 'be filled with enthusiasm, be inspired' there is a component шылдырангаш $v$. (lit.: lend wings) 'be inspired, be encouraged, feel a thirst for activity, joyful elation', which has high and lyrical coloring: Ти войнан тыл лоэш рельсна цат вурсангын, / Шылдырангын кредал налмы цаш (Matyukovskiy, 1996). 'Our rails became harder in the fire of this war, the conquered happiness lent wings'.

The poetic coloring attaches to a word вашкаш v. 'hurry, be in a hurry, hasten' belonging to the synonymic series with a dominant талашаш $v$. - the main word with common meaning 'try to do something, get somewhere as soon as possible; do something quickly, trying not to be late, not to miss': Уже пыш доно талашат / Чынь матросвла тыдын док --- (Matyukovskiy, 1996). 'Sailors hurry already on boats to him ---'. Сталинградыш, Сталинградыш / Ружге вашкат циланат (Matyukovskiy, 1996). 'Everybody is in a hurry to Stalingrad, to Stalingrad'.

In the Hill Mari language there are paired words which have folk poetic coloring. They show higher expressiveness and melodiousness in comparison with single synonyms. According to E.N. Mustaev, method of pairing of two 
semantically close or even identical words is characteristic to oral folk creative works (Mustaev, 2000). Among paired words as components of synonymous series from the works by $\mathrm{G}$. Matyukovskiy we can point out тыл-шыкш $n$. 'firesmoke', тыл-выр n. 'fire-blood', йыр-йырваш adv. 'all around, everywhere', качкаш-йуаш v. 'eat and drink', ясы-орльк n. 'grief-suffering', ушты-шокшы adj. (lit.: cold and heat) 'misfortune, deprivation', ясы-худа $n$. 'difficulties, unhappiness', ясы-нелы $n$. 'difficulty-gravity', улан-паян adj. 'rich, wealthy', йанг-шум n. 'soul-heart', уты-ситы $n$. 'excessivenesssufficiency, drawback, shortcoming', and others.

We review the use of the paired word ymы-сumы $n$. 'excessiveness-sufficiency, drawback, shortcoming', which is a component of a synonymous series with the dominant акъяры $n$. 'uselessness, unacceptability, inadmissibility'. The common meaning of the series is 'unnecessary negative quality of someone, something': Пенсионер, акъярым выкы лыктын, / Пыт порядок верц кредалеш со (Matyukovskiy, 1983). 'The pensioner pointing out the flaws, always fiercely fights for the order'. Яжо сага вет мамнажын / Улы уты-ситыжы (Matyukovsky, 1983). 'Besides all the good qualities we have some shortcomings'.

The word идалык $n$. 'time marked with important (usually strained, difficult) events' acquires high or traditionalpoetic coloring in comparison with its commonly used synonyms жеп n., верема $n$. which coincide in the meaning 'time, period':

Ой, тынь, сар шыжы верема, иктат тыньым ак мондеп, рвезывлан салтакыш кемы, йангын тыргыжланым жеn (Matyukovskiy, 1996)! 'Oh, you, yellow autumn period, no one will forget you, it's time to send off soldiers, anxious time!' Мыньжы ынде «Цевер!» манам / Цила героемлан. / Мишукемлан да Ниналан, / Патыр мары халыклан, / Ку сандалык вери шагалын / Нелы ти идалыкын (Matyukovskiy, 1986). 'And now I say goodbye to all my characters, Mishka and Nina, the brave Mari people who fought for their country in the difficult years'.

About $6 \%$ of functionally painted synonyms in G. Matyukovskiy's poetry belong to the poetic lexis, $5 \%$ - to folk poetic. There are $0.3 \%$ of traditional-poetic synonyms (Fig. 1).

In conclusion, we give quantitive data about synonyms from the works by G. Matyukovskiy. During the study we analyzed 1525 components from 470 synonymic series compiled on the basis of lexis from G. Matjukovskiy's poetic works. Synonyms were considered from the point of view of attachment to different functional styles. We marked the functional-stylistic coloring of synonyms and deduced quantitative parities of synonyms with various coloring. Common synonyms which do not have functional coloring made the greatest group among all the synonyms (1229 units, $80.5 \%$ ). The synonyms used in colloquial and bookish styles are in the ratio 4 to 1 accordingly.

Among synonyms of colloquial style there are components with daily colloquial, low colloquial and rude colloquial colorings. The synonyms with daily colloquial coloring are the most numerous. Low colloquial synonyms are almost three times less than daily colloquial ones, however they make the second big group among synonyms with functional-stylistic coloring. Rude-colloquial synonyms are seldom met in G. Matyukovskiy's poetry.

1/4-th part of bookish synonyms owing to absence of functional-stylistic coloring were not specified and we left them as bookish. Among bookish synonyms there is a small share of synonyms of scientific style. In the group of synonyms of belles-letter style poetic synonyms are the most numerous, the second in majority group is presented by folk poetic synonyms, traditional-poetic synonyms are the least.

Having the given quantity data, it is possible to tell that G. Matyukovskiy uses a large supply of means of the Hill Mari language, synonyms, basically, of common and colloquial styles of speech. His works are clear and close to common people and on the whole to a wide range of readers. With the use of synonyms he comprehensively describes and concretizes actions, subjects, phenomena, human qualities. Synonyms with various functional-stylistic coloring serve for creation of atmosphere of described events, the positive or negative attitude to all events in poems.

The poet also uses a set of means of the bookish style, which allowing to give verses raised or lyrical tone.

As a result of the research it is possible to assert that deducing a quantitative parity of synonyms is one of ways to describe author' language.

\section{References}

Gorbachevich, K.S. (2008). Dictionary of synonyms of the Russian language. Moscow: Eksmo. Kozhina, M.N. (2006). Stylistic encyclopedic dictionary of the Russian language. Moscow: Flinta, Nauka Publ. Matyukovskiy, G.I. (1996). Selected verses and poems. Yoshkar-Ola.

Matyukovskiy, G.I. (1986). On the way to victory. Yoshkar-Ola: Mari book publishers.

Matyukovskiy, G.I. (1983). Motherland. Verses and poems. Yoshkar-Ola: Mari book publishers.

Mustaev, E. N. (2000). Dictionary of synonyms of the Mari language. Yoshkar-Ola: Mari book publishers.

Opleva, I.V. (2009). Connotation of synonyms in the works by G. Matyukovskiy. Journal: New mood.160, 98-100.

Opleva, I.V. (2009). Synonyms as tropes in the poetry of G. Matyukovskiy. Journal: Herald of the Chuvash University, 556, $256-261$. 
Savatkova, A.A. (1981). Dictionary of the Hill Mari dialect of the Mari language. Yoshkar-Ola: Mari book publisher.

Trubyanova, Irina, (2013), Stylistic coloring of phraseological synonyms in the Hill Mari language (on the basis oworks by G. Matyukovskiy). [Online] Available: http://www.science-education.ru/113-11810 (2013)

Yartseva, V.N. (1990). Linguistic encyclopedic dictionary. Moscow: Sov. Encyclopedia.

Yevgenyeva, A.P. (2003). Dictionary of synonyms of the Russian language: in 2 vol. Vol. 1: A-N. Moscow: «Astrel' Publishers» Ltd., «AST Publishers» Ltd. 